\title{
MUHAMMADIYAH IDEOLOGY: AFFIRMATIVE ACTION FOR LGBT BASED ON NAWACITA
}

\author{
Ardian Bakhtiar Rivai \\ Department of Civics Education \\ Universitas Ahmad Dahlan Yogyakarta, Indonesia \\ ardian.rivai@ppkn.uad.ac.id
}

\begin{abstract}
It is clear that Lesbian, Gay, Bisexual, and Transgender is new phenomena in Indonesia which is make a new controversy today. There are two perspective which debate about how society to accept and reject this phenomena. This study aims to promote the idea of affirmative action for LGBT in the school. A questionnaire was use to capture about the student opinion about LGBT and how to treat LGBT in the daily life. The survey result of the research shows that student in Yogyakarta had good tolerance and contribute to give affirmative action in the school. In addition, the enlightening spirit of Muhammadiyah is to make LGBT change their orientation by soft treatment especially in the Muhammadiyah school. In conclusion, this study assumption that affirmative action for LGBT based on Muhammadiyah value is the most effective strategy to make mental revolution will be success for LGBT especially in Yogyakarta.
\end{abstract}

Keywords: ideology, LGBT

\section{INTRODUCTION}

This study intends to determine how public opinion on LGBT (Lesbian, Gay, Bisexual, and Transgender). Nowadays, LGBT was legalized in the United States of America. This social phenomenon raises a logical consequence of the public opinion around the world, including Indonesia. In the study of political science, there are two major ideas, about how to understand this LGBT's phenomena. First of all, a biological approach. They are holding on to this approach believe that LGBT is a social phenomenon which is caused by abnormalities or genetic fault that there are different sexual disorientation with people in general.

Secondly, the sociological approach. They are holding on to this approach assumes that human existence with LGBT habit is caused by environmental factors which support individuals to apply like others of its kind. In understanding the sociological approach, groups of people with LGBT habits are formed for their construction of environment. In consequently, everyday habits that leads individual to behave not as common as human beings in general

In the debate of the two approaches, there are two perspectives to see how about LGBT in Indonesia which are religious norms and cultural values in Indonesia are contradictory and forbidden [1]. The existence of LGBT behavior in Indonesia perspectives was strictly forbidden and bizarre. On the other hand, LGBT groups, which use the momentum endorsement of their behavior in the United States as a form of their struggle so that the Indonesian government could do the same thing as happened in the United States. This study aims to promote the idea of affirmative action for LGBT in the school. A questionnaire was use to capture about the student opinion about LGBT and how to treat LGBT in the daily life.

\section{RESEARCH METHOD}

This study uses a quantitative approach This study intends to determine how public opinion on LGBT (Lesbian, Gay, Bisexual, and Transgender). Using a survey instrument to promote the idea of affirmative action for LGBT in the school. This research social phenomenon raises a logical consequence of the public opinion around the world, including Indonesia.

\section{RESULT FINDINGS AND DISCUSSION}

This study found that the majority of students do not agree with the form of legalization LGBT movement in Indonesia. The survey results showed that $93 \%$ of respondents did not agree with the legalization of LGBT in Indonesia, 6\% undecided, and the remaining $1 \%$ approve if LGBT legal in Indonesia. In the perspective of the management of public policies, the modern university is an institution of higher education to embrace and accommodate all interests of its academic community who come from different ethnic backgrounds, ethnicities, or even a different religion [1]. The idea of affirmative action for LGBT charitable efforts as a place of enlightenment (ladang pencerahan), it is actually another form of ijtihad from what was once done by Andrew Wylie at Indiana University [1].

The modern university is ideal to be able to provide enlightenment for LGBT people to get out of the abyss of their contempt for this. Conversely, the modernization of universities is also an encouragement which not only gives change in the gender diversity, but far from it, the aspect of religious sectarianism will also be important to consider as momentum of progressive enlightenment. Researcher are very inspired by how thoughts Andrew Wylie who built the Indiana 
University campus is committed to be able to embrace all of its academic community with a basic understanding of nonsectarian, nondenominational, which led to the higher education system with strong leaders [1]. Such a way of thinking which is really a method for building a strategy and to build a university environment where is open to all the citizens, including ethnic or ethnically diverse.

Andrew Wylie adopted the understanding adhering to the cultural values and norms typical of Indonesia established paradigm of research on positions that LGBT people's good not to be discriminated against. In fact, they are driven in the direction of the truth and given an equal footing so that they can get out of the habit of insult that they have done so far. This research is not only to pro or contra about the LGBT movement. This research is just to try to offer another way of thinking that is more welcoming to minorities such as LGBT people in order to find a way of living which ablaze without any intimidation aspect in it.

Indeed affirmative learning environment is an integral part to change the orientation of thinking and character of individuals and groups [2]. The concept of mental revolution in the education space is the most effective strategy to helping individuals or groups of LGBT straighten their way of thinking for the better. The pattern of relationships that understands the school as a network of affirmative action can be explained in three patterns. Firstly, the inputs of students at the university who have a diversity of background characteristics and attitudes have a close relationship with the individual's interes. Attitude to political and racial orientation is very strong in the outlook freshman. Strong orientation and thought in the early days of the study is the result of the educational process at the level of the previous or the result of the formation received character of the neighborhood and the family.

Secondly, higher education environments that are manifested from the institutional context of the learning experience which shape attitudes to political orientation, racial prejudice, structured opportunities in higher education environments [2].

Thirdly, mechanism of social work in a school environment where produce outcomes of affirmative paradigms and new thinking orientation for individuals and LGBT groups. There is a kind of parable of thinking related extreme when LGBT group is being discriminated against, then it will bring firmness of their principles. However, discrimination also will make LGBT to find a way to think of new and further strengthen their understanding because apart united by a common fate as victims of discrimination. LGBT groups also will assume the perpetrator of discrimination as a common enemy that further strengthening their unity in the LGBT community.

The survey results found that $93 \%$ of students support if there are friends who change their mental and orientation of thinking to no longer as part of the LGBT group. $6 \%$ of respondents are not concerned about mental revolution for LGBT. And the remaining 1\% of respondents did not support the idea of affirmative action for LGBT in order to change LGBT orientation in accordance with the norms of religion and decency in Indonesia.

In general, there are four stages at Meuwisse et al (2010) to brighten LGBT within the university. Firstly, learning environments which conducive for minorities such as LGBT. Conducive learning environment is able to make a comfortable student to develop and actualize themselves in campus [3]. Construction learning environment like this is in order to build comfort LGBT student group who is socially more frequently ostracized or discriminated against. This model offers a reverse logic, that if there is a group that wrong thinking and not to be intimidated or discriminated against, but rather groups or people who like this is just had to be given a special position and special treatment to be pulled toward the right path.

Secondly, the stage of interaction within the university where is divided into two aspects. There are formal and informal aspects. Formal aspects require interaction lecturers and students personally and publicly. In the aspect of informal, there are personal and public support interaction between lecturers and students is very important to help those who wrong orientation can be enlightened and encouraged the right thinking [3].

Thirdly, when the university in stable environment already awakened, formal and informal interaction with educators also held comfortably, it will automatically form a sense of belonging as a part of the majority of academicians in universities. The creation of a sense of belonging is the entrance to the success of enlightenment that can be done to the LGBT group to dissolved in the mainstream currents that the majority have a view that in accordance with religious values and morals in Indonesia.

Affirmative action is a strategy which able to rule out discriminatory manner that will create a frontal resistance movement of pro-LGBT. The movement with methods that are structured to undermine opposition from LGBT groups can only be done in ways subtle but still the heart of the main goals. In view of the way of discriminatory will never solve the root of the problem but will lead a new problems [4]. Affirmative action is actually a persuasive effort to attract those belonging to the LGBT people to be pulled toward a path of the truth.

Essentially, affirmative action for LGBT can be developed further to address LGBT errors that are not only just in the university environment. There are four servings that can be developed to understand the affirmative action for LGBT [5]. First of all, affirmative action for LGBT can decrease social differences. In many times a discrimination against certain groups will bring the disparity material that 
will cause resistance from groups that are discriminated. Secondly, labor market discrimination. Affirmative action for LGBT groups will fade and pressing the group to be discriminated against in getting a job at the same time will be more pleased to unite with fellow LGBT group, so that it will keep them afloat and strong understanding of the LGBT because united by the same fate.

Thirdly, affirmative action can decrease of stigmatization in social life. Stigma in the community to LGBT groups will actually make those who remained on the identity of all of LGBT will be stronger and fanatics to stay afloat with the paradigm of LGBT. Fourthly, affirmative action can destruct their common history. One thing is quite important that unites LGBT people is the similarity of their past history so that they remain to this day and will continue to survive on, because it is united by a common history.

Thus, to be able destructing wall of the understanding of LGBT people to be drawn and enlightened towards the right path, then fifthly, it should be torn down first. As a follow-up to tear down those walls, this study also implemented strategies of mental revolution which became one of the strategies in Nawacita by President Joko Widodo and Jusuf Kalla.

In order for LGBT enlightenment and moral values that are contrary to the cultural treasures of Indonesia, this study borrows ideas Nawacita as a foothold for the mental revolution. There are nine ideas that pioneer by Nawacita. First, bring back the state to protect the nation and to provide security to all citizens. Second, make the government do not miss the building clean governance, effective, democratic, and reliable. Third, build Indonesia from the periphery to strengthen these areas and villages within the framework of a unitary state.

Fourth, decline the weak states by reforming the system and law enforcement, free of corruption, dignified, and reliable. Fifth, improve the quality of Indonesian human life. Sixth, improve people's productivity and competitiveness in the international market. Seventh, realize economic independence by moving the strategic sectors of the domestic economy. Eighth, support for characteristic revolution. Ninth, reinforce all unity and strengthen the social restoration of Indonesia.

Based on the nine principles of Nawacita, this study interesting eighth principle as the essence of the ideas offered. The national character revolution, which is designations popularly known as Mental Revolution inspire this research in an effort to brighten LGBT. Mental revolution with the effects of affirmative action has been stated by Long (2007) that the direct effect of affirmative action in the quality of institutions that merge the minority and the majority in a complex situation. However, the combination of a positive impact on the implementation, will consequent to academic and student's decision to interact with fellow students or even by their teachers at the university [6].

Affirmative action is an overall strategy that directs the understanding between equality approach and as a result of human resource development [7]. Affirmative action in this study is not only to equality for LGBT enlarge or reduce discrimination against LGBT but also to provide an opportunity for LGBT to get back into the norms according to the civilization of Indonesia. Moreover, affirmative action is also understood within the framework of the group, meaning LGBT whole, not just LGBT per individual. It can be relative impact massively to all LGBT people in regions.

\section{CONCLUSION}

The most important value of Muhammadiyah for school paradigm is about progressive and enlightening of life. Based on this paradigm, school is a place to make people better achievement then before they goes to school. It is mean that school is not for the best student only; it can be a place for student with low quality. However, student with low quality must educate in the school to get output the high quality student after went to school. In the same time, school is a place for enlightening student mentality. School must be a place for mental revolution all of people who be a part of the education process. Finally, this paper aim to promote the idea which not intimidate and discriminate LGBT, so they uncomfortable and cannot found the right way of their think. In contrast, LGBT must be support and motivate to get the right think about their orientation and social life in the school and daily life.

\section{REFERENCES}

[1] G. Williams, 2003. "Andrew Wyle and Religion at Indiana University," Indiana Mag. Hist. (March 2003), vol. Vol. 99, no. 1, pp. 2-4.

[2] J. J. Park, 2009. "Taking Race into Account: Charting Student Attitudes towards Affirmative Action," Res. High. Educ., vol. 50, no. 7, pp. 670690

[3] M. P. Meeuwisse, M., Severiens, S. E., \& Born, 2010. "Learning Environment, Interaction, Sense of Belonging and Study Success in Ethically Diverse Student Groups," Reserach High. Educ., vol. 51, no. 6, pp. 528-545.

[4] P. A. Morrison, 1998. "Applying Demographic Analysis in Affirmative Action Disputes: An Instructional Case," Popul. Res. Policy Rev., vol. 17, no. 5 , pp. $457-478$

[5] A. Deshpande, 2013. "Action in India Quest for Equality : Affirmative," vol. 44, no. 2 , pp. $154-163$,

[6] K. E. V. and E. Long, 2003. "Team Teaching Two Sections of the Same Undergraduate Course: A Case Study," Coll. Teach., vol. 51, no. 4, pp. 122-126,

[7] Carol Agócs, 1986. "Affirmative Action, Canadian Style: A Reconnaissance," Can. Public Policy / Anal. Polit., vol. 12, no. 1, pp $148-162$. 